\title{
Arsenite removal in groundwater treatment plants by sequential Permanganate-Ferric treatment
}

\author{
Arslan Ahmad ${ }^{\mathrm{a}, \mathrm{b}, \mathrm{c}, *}$, Emile Cornelissen ${ }^{\mathrm{a}, \mathrm{i}, \mathrm{j}}$, Stephan van de Wetering ${ }^{\mathrm{d}}$, Tim van Dijk $^{\mathrm{d}}$, \\ Case van Genuchten ${ }^{\mathrm{f}}$, Jochen Bundschuh ${ }^{\mathrm{g}, \mathrm{h}}$, Albert van der Wal ${ }^{\mathrm{ce},}$, Prosun Bhattacharya ${ }^{\mathrm{b}, \mathrm{g}}$ \\ ${ }^{\text {a }}$ KWR Water Cycle Research Institute, Nieuwegein, The Netherlands \\ ${ }^{\mathrm{b}}$ KTH-International Groundwater Arsenic Research Group, Department of Sustainable Development, Environmental Science and Engineering, KTH Royal Institute of \\ Technology, Stockholm, Sweden \\ ${ }^{c}$ Department of Environmental Technology, Wageningen University and Research (WUR), Wageningen, The Netherlands \\ d Brabant Water N.V. Breda, The Netherlands \\ e Evides Water Company N.V. Rotterdam, The Netherlands \\ ${ }^{\mathrm{f}}$ Department of Earth Sciences-Geochemistry, Faculty of Geosciences, Utrecht University, Utrecht, The Netherlands \\ ${ }^{g}$ International Centre for Applied Climate Science, University of Southern Queensland, West Street, Toowoomba, Australia \\ h Deputy Vice-Chancellor's Office (Research and Innovation), \& Faculty of Health, Engineering and Sciences, University of Southern Queensland, Toowoomba, Australia \\ ${ }^{\mathrm{i}}$ Singapore Membrane Technology Centre, Nanyang Environment and Water Research Institute, Nanyang Technological University, Singapore \\ ${ }^{\mathbf{j}}$ Particle and Interfacial Technology Group, Ghent University, Ghent, Belgium
}

\section{A R T I C L E I N F O}

\section{Keywords:}

Arsenic removal

Arsenite oxidation

Drinking water

Groundwater treatment

Permanganate

Rapid sand filtration

\begin{abstract}
A B S T R A C T
The Dutch drinking water sector is actively investigating methods to reduce arsenic (As) to $<1 \mu \mathrm{g} / \mathrm{L}$ in drinking water supply. We investigated (1) the effectiveness of sequential permanganate $\left(\mathrm{MnO}_{4}\right)-$ ferric (Fe(III)) dosing during aeration-rapid sand filtration to achieve $<1 \mu \mathrm{g} / \mathrm{L} \mathrm{As} \mathrm{(2)} \mathrm{the} \mathrm{influence} \mathrm{of} \mathrm{MnO}_{4}-\mathrm{Fe}(\mathrm{III})$ dosing on preestablished removal patterns of As(III), $\mathrm{Fe}(\mathrm{II}), \mathrm{Mn}$ (II) and $\mathrm{NH}_{4}{ }^{+}$in rapid sand filters and (3) the influence of $\mathrm{MnO}_{4}-\mathrm{Fe}$ (III) dosing on the settling and molecular-scale structural properties of the filter backwash solids. We report that $\mathrm{MnO}_{4}-\mathrm{Fe}$ (III) dosing is an effective technique to improve arsenite [As(III)] removal at groundwater treatment plants. At a typical aeration-rapid sand filtration facility in the Netherlands effluent As concentrations of $<1 \mu \mathrm{g} / \mathrm{L}$ were achieved with $1.2 \mathrm{mg} / \mathrm{L} \mathrm{MnO}_{4}{ }^{-}$and $1.8 \mathrm{mg} / \mathrm{L} \mathrm{Fe}(\mathrm{III})$. The optimized combination of $\mathrm{MnO}_{4}-$ and $\mathrm{Fe}(\mathrm{III})$ doses did not affect the removal efficiency of $\mathrm{Fe}(\mathrm{II}), \mathrm{Mn}$ (II) and $\mathrm{NH}_{4}{ }^{+}$in rapid sand filters, however, the removal patterns of $\mathrm{Fe}(\mathrm{II})$ and $\mathrm{Mn}$ (II) in rapid sand filter were altered, as well as the settling behaviour of backwash solids. The characterization of backwash solids by Fe K-edge X-ray absorption spectroscopy (XAS) and X-ray diffraction (XRD) showed that the changed settling velocity of backwash solids with $\mathrm{MnO}_{4}-\mathrm{Fe}(\mathrm{III})$ in place was not due to changes in the molecular-scale structure of Fe-precipitates that constitute the major portion of the backwash solids.
\end{abstract}

\section{Introduction}

Arsenic in drinking water is one of the largest human health risks known at the present time, with well over 200 million people around the world being exposed to high As concentrations [1-3]. Arsenic can be released from the Earth's crust into drinking water sources by both natural (e.g. leaching from rocks and sediments, volcanism) and anthropogenic processes (e.g. mining, agrochemicals, wood preservatives) [4-11]. In aqueous environments As may occur in organic and inorganic forms, whereby the latter is known to predominate in fresh water [12-14]. Inorganic As predominantly occurs in two oxidation states; +3 and +5 , with varying level of protonation, depending on the pH [13-16].

Arsenic can cause a number of carcinogenic and non-carcinogenic adverse effects on human health [17-20], however, its mode of action and dose-response characteristics allowing for the identification of a safe exposure level are still not well-understood [13,21-23]. This leads to considerable uncertainties about the actual risks of As exposure, especially at low concentrations [21]. Following a preventive approach, the Dutch drinking water sector is actively investigating treatment options to reduce trace levels of As from drinking water to $<1 \mu \mathrm{g} / \mathrm{L}$ [24]. Groundwater is the main source of drinking water in the

\footnotetext{
* Corresponding author.

E-mail addresses: arslan.ahmad@kwrwater.nl, arslana@kth.se (A. Ahmad).
} 
Netherlands and As concentration in raw groundwater ranges between $<0.5-70 \mu \mathrm{g} / \mathrm{L}[25,26]$. In drinking water, produced at approximately 180 centralized Water Treatment Plants (WTPs), the concentration of As ranges between $<0.5-6.2 \mu \mathrm{g} / \mathrm{L}[25,26]$ which shows that As is removed with varying efficiencies during treatment and the resulting concentrations in drinking water are well below the WHO guideline $(10 \mu \mathrm{g} / \mathrm{L})$.

Most groundwater treatment plants in the Netherlands typically apply aeration followed by rapid sand filtration to accomplish the removal of dissolved iron [Fe(II)], manganese [Mn(II)] and ammonium $\left(\mathrm{NH}_{4}{ }^{+}\right)$from water through distinct removal pathways [27]. Iron(II) may oxidize homogeneously, heterogeneously and biologically, or by a combined mechanism involving these processes, leaving hydrous ferric oxide (HFO) precipitates (Fe(III)-precipitates) in the supernatant, in the pores and on the surface of the filter media [28-30]. Direct oxidation of Mn(II) by oxygen $\left(\mathrm{O}_{2}\right)$ is generally negligible [31,32] and bacteria and surface catalysts on the filter media grains are known to transform Mn (II) to insoluble hydrous manganese oxide $\left(\mathrm{MnO}_{2}\right)[33,34]$. Ammonium is removed by nitrification which takes place in the filter bed, mediated by different bacterial species $[27,35]$. These treatment plants also remove As, attributed to adsorption to the precipitated HFO [25,36], as observed by McNeill and Edwards [37] and Lytle et al. [38] in several groundwater treatment plants in the United States, by Sorlini et al. [39] in Italy and by Katsoyiannis et al. [34] in Greece. The presence of anions in groundwater e.g. phosphate, sulfate, carbonate, silicate, as well as the natural organic matter may reduce the adsorption of As to Fe(III)precipitates due to their competition for adsorption sites [40-45], sometimes rendering the amount of natural Fe in raw water insufficient to achieve the target effluent As concentration. The concentration of Fe nevertheless can be increased by dosing an Fe(III) or Fe(II) based coagulant such as ferric chloride $\left(\mathrm{FeCl}_{3}\right)$ or ferrous sulfate $\left(\mathrm{FeSO}_{4}\right)$. The As removal efficiency may differ when $\mathrm{Fe}(\mathrm{II})$ or $\mathrm{Fe}(\mathrm{III})$ is dosed, per equal concentration of precipitated Fe $[46,47]$. In The Netherlands, $\mathrm{FeCl}_{3}$ is the most widely used coagulant in drinking water production and for this reason we chose it as the source of Fe in this study.

The adsorption of As to Fe(III)-precipitates is also sensitive to As species in water [44,48-50]. The adsorption of $\mathrm{As}(\mathrm{V})$ to $\mathrm{Fe}(\mathrm{III})-$ precipitates at low As/Fe molar ratios and $\mathrm{pH}$ relevant for most groundwater (6.5-8.5) is more efficient compared to As(III) [32,41,42,51,52], mainly because of the anionic character of $\mathrm{As}(\mathrm{V})$. Therefore, at WTPs where As(III) is a dominant species in source water, (pre-)oxidation of $\mathrm{As}(\mathrm{III})$ to $\mathrm{As}(\mathrm{V})$ could increase As removal. Oxidation of As(III) by dissolved $\mathrm{O}_{2}$ alone is thermodynamically possible, however the reaction proceeds very slowly [53,54], rendering the traditional aeration techniques, e.g. spray or cascade aeration, inefficient in oxidizing As(III) $[28,34,38]$. Chemical oxidants, such as chlorine, ozone, hydrogen peroxide, permanganate $\left(\mathrm{MnO}_{4}-\right)$ etc. have been shown to achieve rapid oxidation of As(III) [55]. In this study $\mathrm{MnO}_{4}$ - was used for $\mathrm{As}(\mathrm{III})$ oxidation because it has the ability to oxidize As(III) over a broad $\mathrm{pH}$ range and within time frame of seconds to one minute [56-58]. Furthermore, $\mathrm{MnO}_{4}$ - does not form harmful by-products such as chlorination in the presence of humic substances [59] and ozonation with bromide present [60] and is easy to dose and affordable [61,62].

Arsenic removal from water involving $\mathrm{MnO}_{4}$ - and $\mathrm{Fe}(\mathrm{III})$ dosing has been previously investigated. Borho and Wilderer [61] demonstrated at pilot scale that $\mathrm{MnO}_{4}$ - dosing followed by $\mathrm{Fe}(\mathrm{III})$ dosing could lead to very low residual As concentration, provided the As containing Fe(III)precipitates were sufficiently removed from water. Lihua et al. [57] studied the $\mathrm{MnO}_{4}$ - and $\mathrm{Fe}(\mathrm{III})$ dosing in water with the aim of developing a small system for rural populations in low income countries. They used tap water spiked with As(III) in their experiments and filtration was accomplished through a sand filter followed by ultrafiltration (UF). It was shown that when water was pre-treated with $\mathrm{MnO}_{4}$ for As(III) oxidation, lower and more stable effluent As concentrations were achieved and the sand filtration was mainly responsible for the removal of As-laced Fe(III)-precipitates. Bordoloi et al. [63] studied As
(III) removal from groundwater water by $\mathrm{MnO}_{4}$ and $\mathrm{Fe}(\mathrm{III})$ dosing at mild alkaline $\mathrm{pH}$ that was achieved through the addition of $\mathrm{NaHCO}_{3}$ in water. Their study was also aimed at developing a process for rural application in low income countries. With laboratory and field experiments, Bordoloi et al. [63] showed that As(III) could be efficiently removed to meet the WHO guideline for As in drinkingwater $(10 \mu \mathrm{g} / \mathrm{L})$.

All these studies show that $\mathrm{MnO}_{4}-\mathrm{Fe}(\mathrm{III})$ dosing is a promising method to increase the As(III) removal efficiency at typical aeration-rapid sand filtration type groundwater treatment facilities where As(III) is present in the raw water, however As removal to $<1 \mu \mathrm{g} / \mathrm{L}$, as aimed in this study, has never been a goal of any of the previous studies. The effects of adopting $\mathrm{MnO}_{4}-\mathrm{Fe}(\mathrm{III})$ dosing on the existing removal efficiencies of $\mathrm{Fe}(\mathrm{II}), \mathrm{Mn}(\mathrm{II})$ and $\mathrm{NH}_{4}{ }^{+}$at typical aeration-rapid sand filtration type groundwater treatment facilities are also not well documented in literature. Moreover, the influence on settling characteristics of filter backwash water, which is an important parameter affecting the design and operation of backwash water treatment at WTPs, has not been studied before. Consequently, the aim of this study was (1) to achieve $<1 \mu \mathrm{g} / \mathrm{L}$ As by $\mathrm{MnO}_{4}-\mathrm{Fe}(\mathrm{III})$ dosing at a typical aeration-rapid sand filtration facility (2) to study the influence of $\mathrm{MnO}_{4^{-}}-\mathrm{Fe}(\mathrm{III})$ dosing on the removal of As, $\mathrm{Fe}, \mathrm{Mn}$ and $\mathrm{NH}_{4}{ }^{+}$in rapid sand filtration and (3) to study the influence of $\mathrm{MnO}_{4^{-}}-\mathrm{Fe}(\mathrm{III})$ dosing on the settling and molecular scale structural properties of the filter backwash solids. The study, including batch, pilot and full-scale experiments, was carried out at a groundwater treatment facility (WTP Dorst) in the Netherlands with typical aeration-rapid sand filtration based treatment scheme.

\section{Materials and methods}

\subsection{Treatment layout and water quality of WTP Dorst}

WTP Dorst is a typical groundwater treatment facility $\left(10 \mathrm{Mm}^{3} /\right.$ year production) in the Netherlands which treats anaerobic groundwater in 10 parallel treatment trains, each comprising of a cascade aeration step followed by a submerged rapid sand filter (Fig. 1). The surface area and bed height of the sand filters are $27 \mathrm{~m}^{2}$ and $1.8 \mathrm{~m}$ respectively. They contain a single media filter material (silica sand D50 $=1.3 \mathrm{~mm}$ ) and are operated at an average (superficial) filtration velocity of $4.6 \mathrm{~m} / \mathrm{h}$ (filter loading $\mathrm{Q}=125 \mathrm{~m}^{3} / \mathrm{h}$ ). Table 1 presents the raw and treated water quality at WTP Dorst.

\subsection{Optimizing $\mathrm{MnO}_{4^{-}}$and $\mathrm{Fe}(\mathrm{III})$ doses to achieve $<1 \mu \mathrm{g} / \mathrm{L} \mathrm{As}$}

\subsubsection{Preliminary batch experiments}

To gain preliminary information on $\mathrm{MnO}_{4^{-}}$and $\mathrm{Fe}(\mathrm{III})$ doses required to remove As to $<1 \mu \mathrm{g} / \mathrm{L}$, a series of batch tests was carried out using the raw water of WTP Dorst (Table 1). The experiments were performed with a jar test apparatus, which comprised a set of six transparent jars (2 L capacity each). Each jar was equipped with a dosing unit to add $\mathrm{MnO}_{4^{-}}$and $\mathrm{Fe}(\mathrm{III})$, a paddle for mechanical stirring and a sampling point in the bottom. The timing of $\mathrm{MnO}_{4^{-}}$and $\mathrm{Fe}(\mathrm{III})$ dosing and mixing speed in the jars could be automatically controlled. A $0.03 \mathrm{M} \mathrm{KMnO}_{4}\left(3.6 \mathrm{~g} / \mathrm{L} \mathrm{MnO}_{4^{-}}\right)$solution was used to dose $\mathrm{MnO}_{4^{-}}$. It was prepared by dissolving $948 \mathrm{mg}$ of solid $\mathrm{KMnO}_{4^{-}}\left(\right.$Cairox ${ }^{\circledR}$, Carus Corporation) in $200 \mathrm{~mL}$ deionized (DI) water directly before the start of the batch experiments. $\mathrm{A} \mathrm{FeCl}_{3}$ solution $(2.0 \mathrm{~g} \mathrm{Fe}(\mathrm{III}) / \mathrm{L})$ was used to dose $\mathrm{Fe}(\mathrm{III})$ in water. It was prepared by dissolving $1936 \mathrm{mg}$ solid $\mathrm{FeCl}_{3} \cdot 6 \mathrm{H}_{2} \mathrm{O}$ (J.T. Baker ${ }^{\circledast}$ ) in $200 \mathrm{~mL}$ DI water directly before the start of the batch experiments.

The jar test procedure was designed to represent the process conditions at the full-scale facility, especially with respect to the residence time of water during aeration and rapid sand filtration. The jar test procedure included the following steps. Firstly, the 6 jars were filled with anaerobic raw groundwater of WTP Dorst (Table 1). Afterwards, a predetermined aliquot of $\mathrm{MnO}_{4^{-}}$and/or $\mathrm{Fe}(\mathrm{III})$ was dosed in each jar 


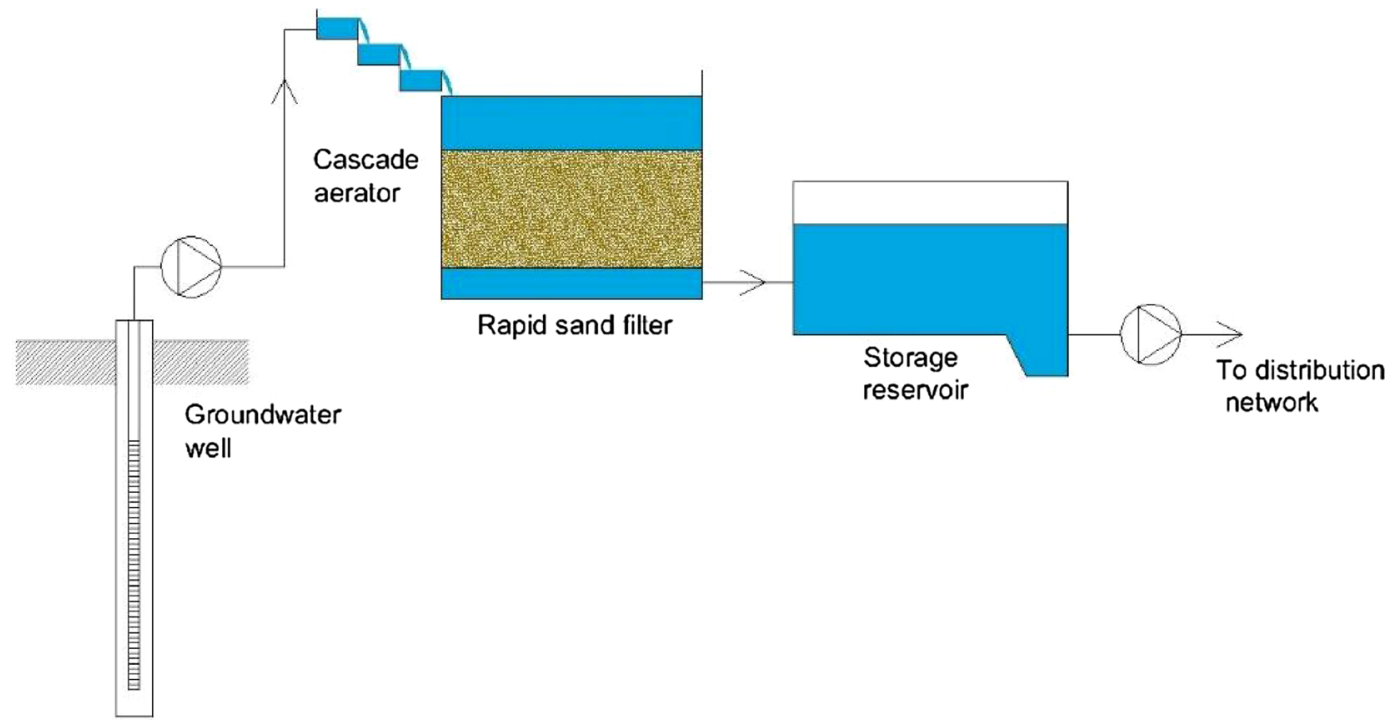

Fig. 1. Typical groundwater treatment layout in the Netherlands.

Table 1

Raw and treated water quality of WTP Dorst.

\begin{tabular}{lllll}
\hline Parameters & Unit & Raw water & $\begin{array}{l}\text { Treatment Plant } \\
\text { Effluent (Drinking } \\
\text { water) }\end{array}$ & $\begin{array}{l}\text { Dutch guidelines for } \\
\text { drinking water } \\
\text { quality }\end{array}$ \\
\hline $\mathrm{pH}$ & & $7.6 \pm 0.1$ & $7.7 \pm 0.1$ & $7.0<\mathrm{pH}<9.5$ \\
$\mathrm{Temp}$. & ${ }^{\circ} \mathrm{C}$ & $12.2 \pm 0.7$ & $12.4 \pm 0.6$ & $\leq 25$ \\
$\mathrm{EC}$ & $\mu \mathrm{S} / \mathrm{cm}$ & $410 \pm 20$ & $406 \pm 10$ & $\leq 1250$ \\
$\mathrm{HCO}_{3}{ }^{-}$ & $\mathrm{mg} / \mathrm{L}$ & $251 \pm 25$ & $240 \pm 10$ & $>60$ \\
$\mathrm{Total} \mathrm{As}^{\times}$ & $\mu \mathrm{g} / \mathrm{L}$ & $11.9 \pm 1.0$ & $6.2 \pm 0.7$ & $\leq 10$ \\
$\mathrm{As}(\mathrm{III})^{¥}$ & $\mu \mathrm{L} / \mathrm{L}$ & $11.7 \pm 1.0$ & $0.8 \pm 0.1$ & - \\
$\mathrm{Fe}(\mathrm{II})$ & $\mu \mathrm{g} / \mathrm{L}$ & $1400 \pm 70$ & $<10$ & $\leq 200$ \\
$\mathrm{Mn}(\mathrm{II})$ & $\mu \mathrm{g} / \mathrm{L}$ & $40 \pm 10$ & $<10$ & $\leq 50$ \\
$\mathrm{NH}_{4}{ }^{+}$ & $\mathrm{mg} / \mathrm{L}$ & $0.55 \pm 0.1$ & $<0.03$ & $\leq 0.2$ \\
$\mathrm{Ca}{ }^{+2}$ & $\mathrm{mg} / \mathrm{L}$ & $65 \pm 4$ & $66 \pm 3$ & - \\
$\mathrm{Mg}^{+2}$ & $\mathrm{mg} / \mathrm{L}$ & $6.9 \pm 0.4$ & $7.5 \pm 0.3$ & - \\
$\mathrm{TOC}^{+2}$ & $\mathrm{mg} \mathrm{C} / \mathrm{L}$ & $2.4 \pm 0.2$ & $2.1 \pm 0.2$ & - \\
\hline
\end{tabular}

"Drinkwaterbesluit, 2008 (available at http://wetten.overheid.nl/ BWBR0030111/2015-11-28) ${ }^{\times}$After implementation of $\mathrm{MnO}_{4^{-}}-\mathrm{Fe}(\mathrm{III})$ dosing As $=0.6 \pm 0.1 \mu \mathrm{g} / \mathrm{L}$ in treatment plan effluent. ${ }^{¥}$ After implementation of $\mathrm{MnO}_{4^{-}}-\mathrm{Fe}(\mathrm{III})$ dosing $\mathrm{As}(\mathrm{III})<0.5 \mu \mathrm{g} / \mathrm{L}$ in treatment plan effluent.

while the solutions were mixed at $300 \mathrm{RPM}$. In the $\mathrm{MnO}_{4}-\mathrm{Fe}(\mathrm{III})$ dosing experiments, the interval between $\mathrm{MnO}_{4^{-}}$and $\mathrm{Fe}(\mathrm{III})$ doses was kept constant at $2 \mathrm{~min}$. This interval was chosen to make sure that complete oxidation of As(III) to As(V) occurred before Fe(III) dosing, though Ghurye and Clifford [56] and Sorlini and Gialdini [58] found complete As(III) oxidation within $1 \mathrm{~min}$ of $\mathrm{MnO}_{4^{-}}$dosing in their experiments with both synthetic and real groundwater samples. After 3 min of mixing at $300 \mathrm{RPM}$, the mixing speed was reduced to $50 \mathrm{RPM}$ for the next $13.5 \mathrm{~min}$ to allow Fe(III) precipitates to grow into larger flocs. Finally, the process water was sampled from the jars by opening the bottom tap and filtering immediately using $0.45 \mu \mathrm{m}$ filters (GE's GD/XP disposable syringe filters with nylon membrane). The filtered samples were analyzed for As and Fe. During the experiments the jars were kept open to the atmosphere, therefore the agitation caused by stirring at 300 RPM not only accomplished mixing of the chemicals, but also aeration of the raw water.

\subsubsection{Pilot experiments}

Pilot experiments were performed to optimize the dosing of $\mathrm{MnO}_{4^{-}}$ and Fe(III). The pilot plant, installed at WTP Dorst, was fed with the raw water of WTP Dorst (Table 1). Fig. 2 shows a schematic diagram of the pilot setup. The pilot setup consisted of an aeration cascade

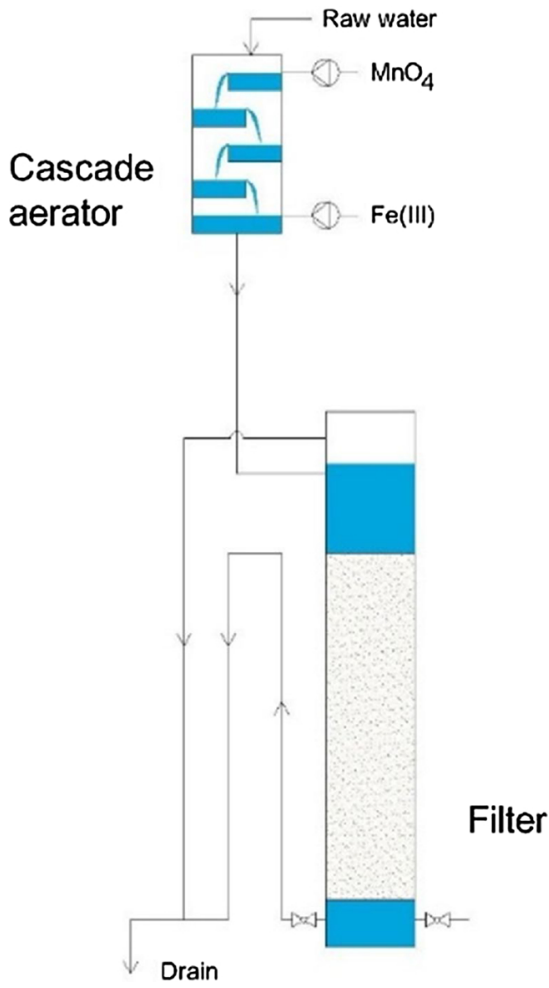

Fig. 2. Schematic diagram of the pilot set-up.

followed by a filtration column ( $0.3 \mathrm{~m}$ diameter, $2.5 \mathrm{~m}$ height $)$ and peristaltic pumps for $\mathrm{MnO}_{4^{-}}$and $\mathrm{Fe}(\mathrm{III})$ dosing. The column contained filtration media ( $1.8 \mathrm{~m}$ height) obtained from the full-scale filter of WTP Dorst (silica sand D50 $=1.3 \mathrm{~mm}$ ) in an attempt to achieve a similar rapid sand filtrate quality as the full-scale facility. Permanganate was dosed using $0.03 \mathrm{M} \mathrm{KMnO}_{4}\left(3.6 \mathrm{~g} / \mathrm{L} \mathrm{MnO}_{4}\right.$ ) solution prepared onsite in $20 \mathrm{~L}$ jerry cans by dissolving solid $\mathrm{KMnO}_{4}\left(\mathrm{Cairox}^{\circledast}\right)$ in DI water 2-3 times per week. Ferric was dosed using $40 \mathrm{w} / \mathrm{w} \% \mathrm{FeCl}_{3}$ solution (Ferralco Nederland BV). $\mathrm{MnO}_{4}$ - was dosed at the top of the cascade for As(III) oxidation and Fe(III) was dosed for As(V) removal at the bottom, as shown in Fig. 2. Two separate membrane pumps (GALA1602, ProMinent ${ }^{\circledR}$ ) were used for dosing $\mathrm{MnO}_{4^{-}}$and $\mathrm{Fe}(\mathrm{III})$.

The pilot experiments were performed under three conditions, 
based on the outcomes of the preliminary batch experiments and further optimization of chemical dosing to achieve $<1 \mu \mathrm{g} / \mathrm{L}$ in pilot filtrate. In the first condition, the pilot plant was operated for 6 weeks without dosing of $\mathrm{MnO}_{4}$ - and $\mathrm{Fe}(\mathrm{III})$ to replicate a filtrate quality similar to that of the full-scale facility. In the second condition, $0.8 \mathrm{mg} / \mathrm{L} \mathrm{MnO}_{4^{-}}$ and $1.8 \mathrm{mg} / \mathrm{L} \mathrm{Fe}(\mathrm{III})$ were dosed for 4 weeks, and in the third condition, $1.2 \mathrm{mg} / \mathrm{L} \mathrm{MnO}_{4^{-}}$and $1.8 \mathrm{mg} / \mathrm{L} \mathrm{Fe}(\mathrm{III})$ were dosed for 4 weeks in the pilot cascade. During all the experiments the pilot was operated at the filtration velocity of $4.6 \mathrm{~m} / \mathrm{h}$ (filter loading $\mathrm{Q}=1.3 \mathrm{~m}^{3} / \mathrm{h}$ ). Unfiltered and $0.45 \mu \mathrm{m}$ filtered samples were collected from the pilot filtrate during 8-12 runs at each condition and analyzed for the determination of As, $\mathrm{Fe}, \mathrm{Mn}$ and $\mathrm{NH}_{4}{ }^{+}$concentrations.

\subsection{Influence of $\mathrm{MnO}_{4}-\mathrm{Fe}$ (III) dosing on removal of $\mathrm{As}, \mathrm{Fe}, \mathrm{Mn}$ and $\mathrm{NH}_{4}{ }^{+}$}

Soon after the completion of the pilot experiments, the full-scale facility received an upgrade with $\mathrm{MnO}_{4^{-}}-\mathrm{Fe}$ (III) dosing. This enabled us to study the influence of $\mathrm{MnO}_{4}-\mathrm{Fe}(\mathrm{III})$ dose on the removal of As, $\mathrm{Fe}$, $\mathrm{Mn}$ and $\mathrm{NH}_{4}{ }^{+}$on full-scale. Reference measurements were obtained before the upgrade, i.e. when the raw water (Table 1) was only treated with aeration-rapid sand filtration. The measurements with $\mathrm{MnO}_{4^{-}}-\mathrm{Fe}$ (III) dosing were obtained one year after the upgrade, with $1.2 \mathrm{mg} / \mathrm{L}$ $\mathrm{MnO}_{4^{-}}$and $1.8 \mathrm{mg} / \mathrm{L} \mathrm{Fe}(\mathrm{III})$ dosed (dosing was based on the results of the pilot experiments) to achieve $<1 \mu \mathrm{g} / \mathrm{L}$ As in the produced drinking water. In both sampling campaigns, unfiltered and $0.45 \mu \mathrm{m}$ filtered raw water, supernatant and filtrate samples were collected. Supernatant refers to the water storage on the top of the filter bed. Concentrations of $\mathrm{As}, \mathrm{Fe}$ and $\mathrm{Mn}$ were determined in unfiltered and $0.45 \mu \mathrm{m}$ filtered samples. Concentrations of $\mathrm{NH}_{4}{ }^{+}$were determined in unfiltered samples only. Dissolved arsenic species were determined in $0.45 \mu \mathrm{m}$ filtered samples.

\subsection{Influence of $\mathrm{MnO}_{4^{-}}-\mathrm{Fe}$ (III) dosage on filter backwash solids characteristics}

The influence of $\mathrm{MnO}_{4}-\mathrm{Fe}(\mathrm{III})$ dosing on the settling and molecular scale structural characteristics of the backwash solids was also studied at the full scale installation. Backwash water samples were collected under 3 conditions: (1) without dosing (no dose), i.e. prior to the upgrade (2) with only dosing $1.2 \mathrm{mg} / \mathrm{L} \mathrm{MnO}_{4^{-}}$and (3) with dosing $1.2 \mathrm{mg} /$

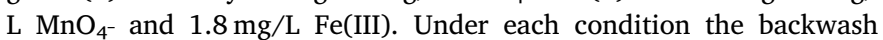
water sample were collected at the 60th hour of the filter run. To collect each sample during filter backwash, $5 \mathrm{~L}$ of backwash water was collected every minute during the first $4 \mathrm{~min}$. The samples were subsequently mixed to form a secondary suspension, which was subsequently used for settling experiments and for solids characterization. Unfiltered and $0.45 \mu \mathrm{m}$ filtered backwash water samples, collected at each setting, were analyzed for Fe and Mn concentration.

\subsubsection{Settling characteristics of filter backwash solids}

The settling characteristics of the filter backwash solids were studied using a method previously used by Van Genuchten et al. [64]. 1.8 L transparent jars were filled with the backwash water samples, mixed with a magnetic stirrer for $1 \mathrm{~min}$ to achieve a homogeneous suspension of filter backwash solids and then allowed to settle under gravity for $1 \mathrm{~h}$. During settling, an aliquot of sample was taken approximately $10 \mathrm{~cm}$ below the surface of the suspension, every $15 \mathrm{~min}$ between $\mathrm{t}=0$ and $60 \mathrm{~min}$, using a wide-mouthed syringe for turbidity measurements using a Hach $2100 \mathrm{~N}$ Turbidimeter. The settling behaviour was also recorded through photographs.

\subsubsection{Solid phase characterization}

Solids were collected on $0.45 \mu \mathrm{m}$ filters from the backwash water samples under no dose and $1.2 \mathrm{mg} / \mathrm{L}^{\mathrm{MnO}_{4^{-}}}$dose conditions. The samples were air dried for $24 \mathrm{~h}$ at room temperature and then stored in closed containers at room temperature until analysis in 2 weeks. The solids were characterized by Fe K-edge X-ray absorption spectroscopy (XAS) and X-ray diffraction (XRD). Fe K-edge XAS data were collected at the DUBBLE beam line (BM-26) of the European Synchrotron Radiation Facility (ESRF). Spectra were recorded at room temperature in transmission mode out to $\mathrm{k}$ of $13 \AA^{-1}$. X-Ray diffraction measurements (XRD) were performed at the X-Ray facility in Utrecht University, The Netherlands. The Samples for powder XRD measurements, were ground into a powder using an agate mortar and pestle. Powder diffraction patterns were collected with a Bruker D8 Advance diffractometer using $\mathrm{Cu} \mathrm{K}$-alpha radiation and a rotating sample stage. Measurements were performed from 5 to $75^{\circ} 2 \theta$ with $0.02^{\circ}$ step sizes and total data collection time of approximately $4 \mathrm{~h}$ per sample.

\subsection{Analysis of water samples}

Determination of As, Fe and Mn concentrations was carried out by Inductively Coupled Plasma Mass Spectrometry (ICP-MS) (SXERIES 2, Thermo Fisher Scientific) at Aqualab Zuid laboratory in the Netherlands. The detection limits (DLs) for As, Fe, Mn were 0.5, 10 and $10 \mu \mathrm{g} / \mathrm{L}$ respectively. Samples for As, Fe, Mn analysis were preserved immediately after sampling by adding $250 \mu \mathrm{L}$ of $10 \%$ ultra-pure nitric acid $\left(\mathrm{HNO}_{3}\right)$. To obtain $0.45 \mu \mathrm{m}$ filtered samples, GE's GD/XP disposable syringe filters were used. For the determination of Fe and Mn in the backwash water samples, samples were digested in acid and microwaved before ICP-MS. Arsenic speciation (As(III) versus As(V)) was determined using Amberlite ${ }^{\circledR}$ IRA-400 chloride form AIEX resin. The procedure included passing $100 \mathrm{~mL}$ of $0.45 \mu \mathrm{m}$ filtered water through a $30 \mathrm{~mL}$ syringe filled with $20 \mathrm{~mL}$ of the resin. The As concentration that remained in the effluent after contact with the resin was considered to be uncharged As(III). As(V) was calculated by subtracting As(III) from the As concentration in the column influent [65]. $\mathrm{NH}_{4}{ }^{+}$was analyzed by a discrete analyzer spectrophotometry (Aquakem 250, Thermo Scientific) at Aqualab Zuid laboratory (accredited NEN-EN-ISO/IEC 17,025:2005). The method DL was $30 \mu \mathrm{g} / \mathrm{L} \mathrm{NH}_{4}{ }^{+}$.

\section{Results and discussion}

\subsection{Optimizing $\mathrm{MnO}_{4^{-}}$and $\mathrm{Fe}(\mathrm{III})$ doses to achieve $<1 \mu \mathrm{g} / \mathrm{L} \mathrm{As}$}

\subsubsection{Preliminary batch experiments}

To gain preliminary information on $\mathrm{MnO}_{4^{-}}$and $\mathrm{Fe}(\mathrm{III})$ doses required to remove As to $<1 \mu \mathrm{g} / \mathrm{L}$, a series of batch tests was carried out. Fig. 3(a) presents the residual As concentration in function of the Fe(III) dose. An As concentration of $<1 \mu \mathrm{g} / \mathrm{L}$ was not achieved even with a high dose of $\mathrm{Fe}(\mathrm{III})(10 \mathrm{mg} / \mathrm{L})$. The residual concentration of As decreased with increasing $\mathrm{Fe}(\mathrm{III})$ dose which can be attributed to the increasing amount of $\mathrm{Fe}(\mathrm{III})$-precipitates with each incremental Fe(III) dose $[41,44,66]$. The actual raw water of WTP Dorst used in these experiments (Table 1) contained As(III) as the predominant As species. As (III) adsorbs to the Fe(III)-precipitates produced by Fe(III) coagulants in solution [41,52]. Fig. 3(a) shows that the residual As concentration in the absence of Fe(III) dosing was $8.7 \mu \mathrm{g} / \mathrm{L}$, thus significantly lower than the As concentration in the raw water $(11.9 \mu \mathrm{g} / \mathrm{L})$. This reduction can be attributed to coprecipitation of As with the natural $\mathrm{Fe}$ in raw groundwater of WTP Dorst $[37,67]$.

The residual As concentration as a function of $\mathrm{MnO}_{4^{-}}$and $\mathrm{MnO}_{4^{-}}-\mathrm{Fe}$ (III) dose is presented in Fig. 3(b). An As concentration of $<1 \mu \mathrm{g} / \mathrm{L}$ As was achieved when $\geq 1.2 \mathrm{mg} / \mathrm{L} \mathrm{MnO}_{4^{-}}$was combined with an $\mathrm{Fe}$ (III) dose of $2.0 \mathrm{mg} / \mathrm{L}$. Residual As concentrations decreased with increasing $\mathrm{MnO}_{4^{-}}$dose for each $\mathrm{Fe}(\mathrm{III})$ dose and the curves appear to level-off beyond $1.2 \mathrm{mg} / \mathrm{L}$ of $\mathrm{MnO}_{4^{-}}$dose indicating ineffectiveness of further increase in $\mathrm{MnO}_{4^{-}}$dose for As removal. This result indicates that $\mathrm{MnO}_{4^{-}}$ dosages of $<1.2 \mathrm{mg} / \mathrm{L}$ may not be sufficient to completely oxidize As (III) to $\mathrm{As}(\mathrm{V})$, thus limiting the As adsorption to Fe(III)-precipitates that were formed in water due to the oxidation and hydrolysis of the natural 

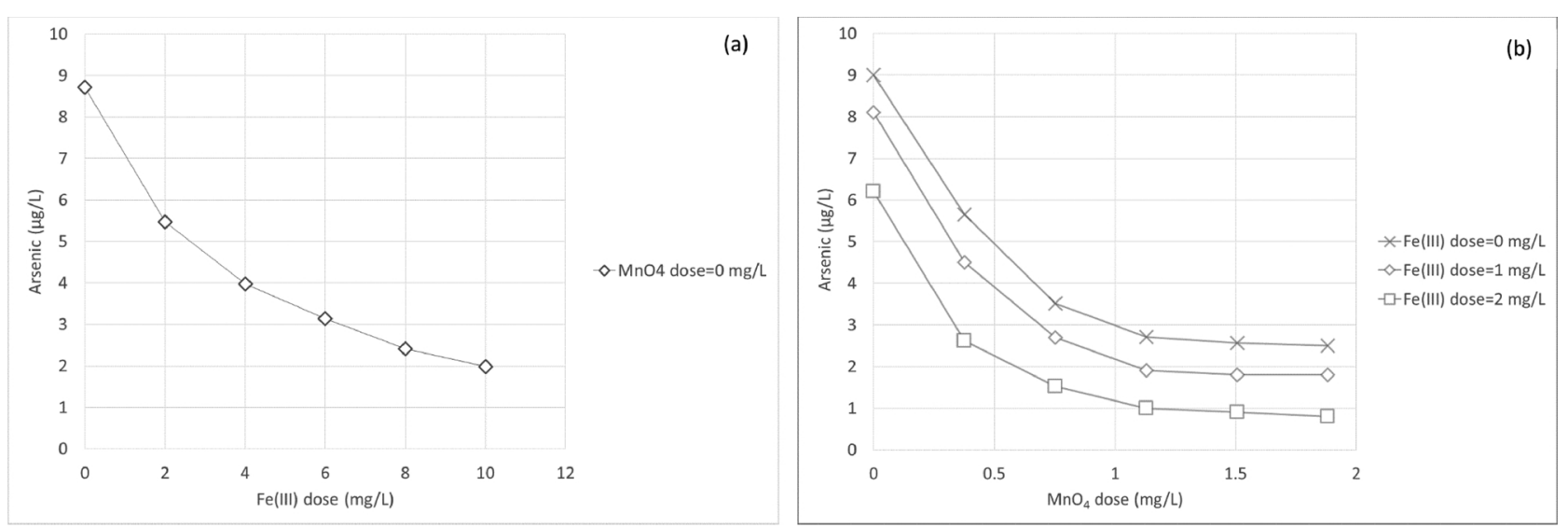

Fig. 3. Residual concentration of As (a) as a function of $\mathrm{Fe}(\mathrm{III})$ dose and (b) as a function of $\mathrm{MnO}_{4^{-}}$and $\mathrm{MnO}_{4^{-}}-\mathrm{Fe}(\mathrm{III})$ dose. Results are based on batch experiments (single trials).

Fe(II) and dosed Fe (III) [32,41,42,51,52]. It is worth mentioning that the residual $\mathrm{Fe}$ concentration in the entire series of batch experiments was $<10 \mu \mathrm{g} / \mathrm{L}$, indicating the $\mathrm{Fe}(\mathrm{III})$ precipitation was not limiting the As removal efficiency.

Comparing the residual As concentrations at $2.0 \mathrm{mg} / \mathrm{L} \mathrm{Fe}(\mathrm{III})$ dose with and without $\mathrm{MnO}_{4^{-}}$(Fig. 3(a) and (b) respectively), it is evident that a significantly lower residual As was achieved when $\mathrm{MnO}_{4^{-}}$and $\mathrm{Fe}$ (III) were dosed. The results of the batch experiments indicated that the

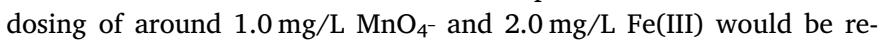
quired to achieve As removal to $<1 \mu \mathrm{g} / \mathrm{L}$ at WTP Dorst. Using these concentrations as a starting point, the next topic is optimizing the $\mathrm{MnO}_{4}-\mathrm{Fe}(\mathrm{III})$ dose in pilot experiments.

\subsubsection{Pilot experiments}

Arsenic and $\mathrm{Fe}$ concentrations in the pilot filtrate are presented in Fig. 4(a) and (b), respectively. In the absence of $\mathrm{MnO}_{4}-\mathrm{Fe}(\mathrm{III})$ dosing, the average As concentration in the pilot filtrate was $6.3 \mu \mathrm{g} / \mathrm{L}$, which was comparable to the full-scale effluent quality (Table 1). However, the pilot filtrate contained a higher Fe concentration $(24.4 \pm 5.3 \mu \mathrm{g} / \mathrm{L})$ (Fig. 4 (b)) compared to the effluent of the full-scale facility where Fe was undetectable $(<10 \mu \mathrm{g} / \mathrm{L})$ (Table 1$)$. When $0.8 \mathrm{mg} / \mathrm{L} \mathrm{MnO}_{4^{-}}$and $1.8 \mathrm{mg} / \mathrm{L} \mathrm{Fe}(\mathrm{III})$ were dosed in the pilot cascade, the As concentration in the filtrate decreased to an average of $1.4 \mu \mathrm{g} / \mathrm{L}$ and the Fe concentration decreased to an average of $21.1 \mu \mathrm{g} / \mathrm{L}$. When the $\mathrm{MnO}_{4^{-}}$dose was increased further to $1.2 \mathrm{mg} / \mathrm{L}$ with $\mathrm{Fe}(\mathrm{III})$ dose maintained at $1.8 \mathrm{mg} / \mathrm{L}$, the As concentration in the filtrate decreased to an average of $0.9 \mu \mathrm{g} / \mathrm{L}$ and the Fe became undetectable $(<10 \mu \mathrm{g} / \mathrm{L})$.

The increased As removal with increment of $\mathrm{MnO}_{4}$ - dose may be due to the oxidation of $\mathrm{As}(\mathrm{III})$ to $\mathrm{As}(\mathrm{V})$ [63] and subsequent more efficient uptake of $\mathrm{As}(\mathrm{V})$ by $\mathrm{Fe}(\mathrm{III})$-precipitates $[42,44,67]$. The Fe speciation (Fe in unfiltered and $0.45 \mu \mathrm{m}$ filtered samples) in the pilot filtrate showed that the dissolved Fe concentration in the pilot filtrate was consistently $<10 \mu \mathrm{g} / \mathrm{L}$ (DL) during the experiments with the three settings. This shows that the precipitation of Fe was not dependent on $\mathrm{MnO}_{4}$ Thus the observed decrease in the Fe concentration in the pilot filtrate with the increase in $\mathrm{MnO}_{4^{-}}$dose from 0 to $1.2 \mathrm{mg} / \mathrm{L}$ was apparently not related to the oxidizing capacity of $\mathrm{MnO}_{4}$. It may, however, be due to improved aggregation (flocculation) and filterability of $\mathrm{Fe}(\mathrm{III})$-precipitates triggered by $\mathrm{MnO}_{\mathrm{x}}$ precipitates that form upon $\mathrm{MnO}_{4^{-}}$reduction and oxidation of natural Mn(II) [57].

Under all three experimental conditions, $\mathrm{Mn}$ and $\mathrm{NH}_{4}{ }^{+}$concentrations in the pilot filtrate remained below the detection limit $(10 \mu \mathrm{g} / \mathrm{L}$ for $\mathrm{Mn}$ and $30 \mu \mathrm{g} / \mathrm{L}$ for $\mathrm{NH}_{4}{ }^{+}$, see S1). This result indicates that the dosing of $\mathrm{MnO}_{4^{-}}$and $\mathrm{Fe}(\mathrm{III})$ did not decrease the overall removal efficiency of $\mathrm{Mn}(\mathrm{II})$ and $\mathrm{NH}_{4}{ }^{+}$in the pilot filter.

It is worth mentioning that the run time of the pilot filter was reduced when $\mathrm{MnO}_{4^{-}}$and $\mathrm{Fe}(\mathrm{III})$ were dosed. This can be attributed to the increased rate of filter clogging due to increased load of Fe(III)-precipitates and $\mathrm{MnO}_{\mathrm{x}}$-precipitates to the filter compared to the condition when $\mathrm{MnO}_{4^{-}}$and $\mathrm{Fe}(\mathrm{III})$ were not dosed.

\subsection{Influence of $\mathrm{MnO}_{4}-\mathrm{Fe}(\mathrm{III})$ dose on $\mathrm{As}, \mathrm{Fe}, \mathrm{Mn}$ and $\mathrm{NH}_{4}{ }^{+}$removal profiles}

Fig. 5 (a, b, c and d) presents As, $\mathrm{Fe}, \mathrm{Mn}$ and $\mathrm{NH}_{4}{ }^{+}$concentrations in the raw, supernatant and filtrate before the upgrade of the full-scale facility (no dose) and after the upgrade when $1.2 \mathrm{mg} / \mathrm{L} \mathrm{MnO}_{4^{-}}$and $1.8 \mathrm{mg} / \mathrm{L} \mathrm{Fe}(\mathrm{III})$ were dosed $\left(\mathrm{MnO}_{4^{-}}-\mathrm{Fe}(\mathrm{III})\right)$. Fig. 5(a) shows that As was approximately $11.5 \mu \mathrm{g} / \mathrm{L}$ in the unfiltered and $0.45 \mu \mathrm{m}$ filtered raw water samples, indicating the presence of As in dissolved form. In the
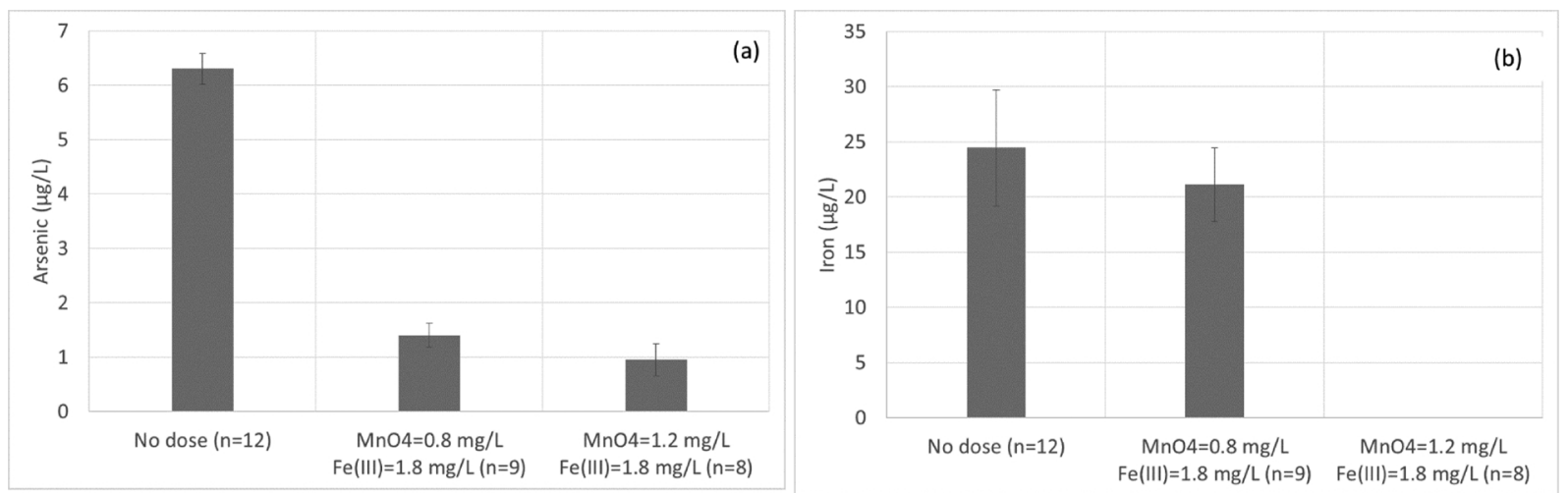

Fig. 4. (a) Arsenic and (b) Fe concentrations in the pilot filtrate under three pilot experimental conditions. 

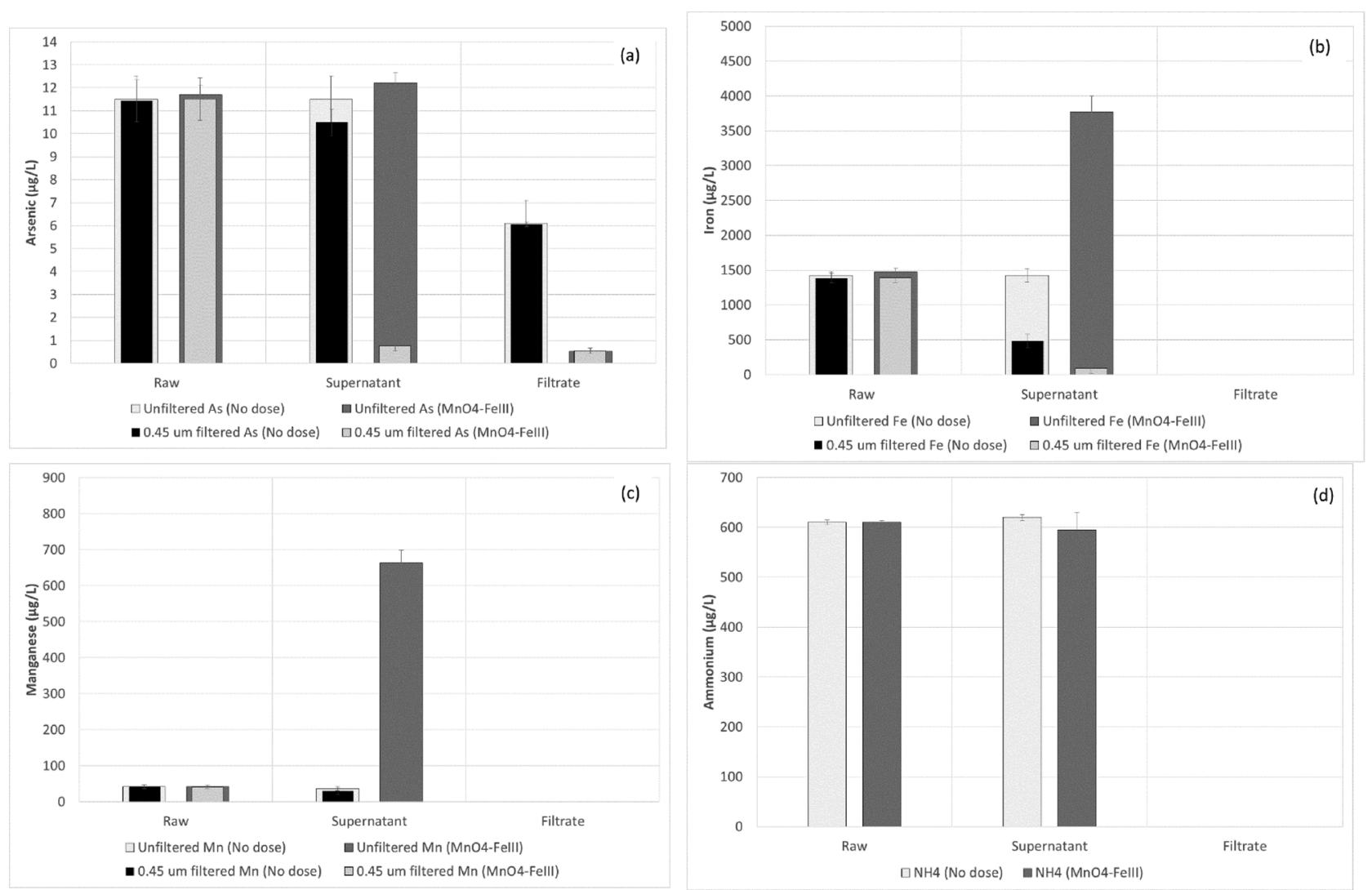

Fig. 5. Concentrations of (a) As, (b) Fe, (c) $\mathrm{Mn}$ and (d) $\mathrm{NH}_{4}{ }^{+}$in unfiltered and $0.45 \mu \mathrm{m}$ filtered raw, supernatant and filtrate without and with $\mathrm{MnO} 4^{-}-\mathrm{Fe}(\mathrm{III})$ dosing. Supernatant refers the water storage on the top of the filter bed.

supernatant, the As concentration in the unfiltered samples was similar to the raw water, indicating that As was not removed during aeration. However, approximately $1 \mu \mathrm{g} / \mathrm{L}$ As $(8.7 \%$ of the total As) was removed by the $0.45 \mu \mathrm{m}$ filter in the supernatant with no dose and $11.4 \mu \mathrm{g} / \mathrm{L}$ (99.2\% of the total As) As became filterable in the supernatant with $\mathrm{MnO}_{4^{-}}-\mathrm{Fe}(\mathrm{III})$ dose. Fig. 5(b) shows that the raw water contained $1400 \mu \mathrm{g} / \mathrm{L} \mathrm{Fe}$, which entirely passed through the $0.45 \mu \mathrm{m}$ filter. In the supernatant, $942.5 \mu \mathrm{g} / \mathrm{L} \mathrm{Fe}(66.2 \%$ of total $\mathrm{Fe})$ passed through the $0.45 \mu \mathrm{m}$ filter in the absence of dosing. The As uptake in the supernatant is calculated to be $(1 / 0.942=) 1.1 \mu \mathrm{g} / \mathrm{mg}$ Fe in the absence of $\mathrm{MnO}_{4}-\mathrm{Fe}(\mathrm{III})$ dosing. The $\mathrm{Fe}$ concentration in the supernatant with $\mathrm{MnO}_{4^{-}}-\mathrm{Fe}(\mathrm{III})$ dose was much higher due to $\mathrm{Fe}(\mathrm{III})$ dosing in the feed, with $3682.3 \mu \mathrm{g} / \mathrm{L} \mathrm{Fe}(97.6 \%$ of the total $\mathrm{Fe})$ filterable through $0.45 \mu \mathrm{m}$ filter. The As uptake in the supernatant is calculated to be (11.4/ $3.37=$ ) $3.3 \mu \mathrm{g} / \mathrm{mg}$ Fe with $\mathrm{MnO}_{4^{-}}-\mathrm{Fe}(\mathrm{III})$ dosing. The 3-fold higher uptake of As in the supernatant with $\mathrm{MnO}_{4^{-}}-\mathrm{Fe}$ (III) dose can be attributed to $\mathrm{As}(\mathrm{III})$ oxidation to $\mathrm{As}(\mathrm{V})$ by $\mathrm{MnO}_{4}$ - $[57,61]$. In the filtrate, a significant difference in As concentration was observed, with $6.1 \mu \mathrm{g} / \mathrm{L}$ at no dose and $0.54 \mu \mathrm{g} / \mathrm{L}$ with $\mathrm{MnO}_{4^{-}}-\mathrm{Fe}(\mathrm{III})$ dose. In both the cases, As passed through the $0.45 \mu \mathrm{m}$ filter, indicating its presence as dissolved As. Iron was below the detection limit $(10 \mu \mathrm{g} / \mathrm{L})$ in the filtrate in both the cases. Since most of the Fe was precipitated in the supernatant, homogeneous $\mathrm{Fe}(\mathrm{II})$ oxidation followed by flocculative removal can be regarded as the principle Fe removal mechanism both at no dose and with $\mathrm{MnO}_{4}-\mathrm{Fe}(\mathrm{III})$ dosing. However, a significantly higher concentration of $\mathrm{Fe}$ was precipitated in the supernatant when $\mathrm{MnO}_{4}-\mathrm{Fe}$ (III) was dosed.

Manganese did not pass through $0.45 \mu \mathrm{m}$ filter in the raw water (Fig. 5(c)), indicating its presence in dissolved form. It remained unfilterable in the supernatant at no dose. This showed that the cascade aeration was ineffective in oxidizing $\mathrm{Mn}(\mathrm{II})$ and confirmed the previous results $[31,32]$ that the transformation of $\mathrm{Mn}(\mathrm{II})$ to $\mathrm{MnO}_{2}$ by dissolved
$\mathrm{O}_{2}$ alone is a slow process at $\mathrm{pH}$ below 9. At no dose, Mn was below the detection limit $(10 \mu \mathrm{g} / \mathrm{L})$ in the filtrate. This $\mathrm{Mn}$ removal can be attributed to the autocatalytic removal mechanism in which dissolved Mn (II) adsorbs to the filter media grains where it is oxidized to form $\mathrm{MnO}_{2}$ coating $[33,34]$. On the other hand, the Mn concentration in the supernatant with $\mathrm{MnO}_{4^{-}}-\mathrm{Fe}(\mathrm{III})$ dose, though much higher due to $\mathrm{MnO}_{4^{-}}$ dosing, was entirely filterable through $0.45 \mu \mathrm{m}$ filter. Thus, Mn entered the rapid sand filter mainly as particles $\left(\mathrm{MnO}_{\mathrm{x}}\right)$ and its removal mechanism in the filter bed changed to flocculative.

At no dose, $\mathrm{NH}_{4}{ }^{+}$removal took place entirely in the filter bed (Fig. 5(d)), which is consistent with biological nitrification [35]. With $\mathrm{MnO}_{4^{-}}-\mathrm{Fe}$ (III) dose, the $\mathrm{NH}_{4}{ }^{+}$concentration in the filtrate remained below the detection limit $(30 \mu \mathrm{g} / \mathrm{L})$, indicating that the nitrification was not affected in the filter bed.

Arsenic speciation was carried out in the raw, supernatant and filtrate samples to gain further mechanistic insight of the As removal process. Fig. 6(a) presents $\mathrm{As}(\mathrm{III})$ and $\mathrm{As}(\mathrm{V})$ concentrations in $0.45 \mu \mathrm{m}$ filtered samples. As(III) was the dominant form of As in the raw water (97.2\%). In the supernatant, As(III) remained dominant (89.6\%), indicating the inefficiency of the cascade aeration in oxidizing As(III) to a significant level, in agreement with Gude et al. [36]. In the filter effluent, the As concentration was lower than the supernatant due to coremoval with $\mathrm{Fe}$ in the filter bed although $\mathrm{As}(\mathrm{V})$ dominated $(80 \%)$. The observed oxidation of As(III) in $9.3 \mathrm{~min}$ of rapid sand filtration was higher-than-expected because As(III) oxidation by dissolved oxygen alone proceeds slowly [53,54]. Similar rapid oxidation of As(III) during rapid sand filtration was reported by Gude et al. [36] and Katsoyiannis et al. [34] and may be attributed to the manganese oxides or microbial activity in the filter bed $[38,46,68]$. With $\mathrm{MnO}_{4}-\mathrm{Fe}(\mathrm{III})$ dosing, the dissolved As in the supernatant and filtrate consisted entirely of $\mathrm{As}(\mathrm{V})$ (Fig. 6(b)). 

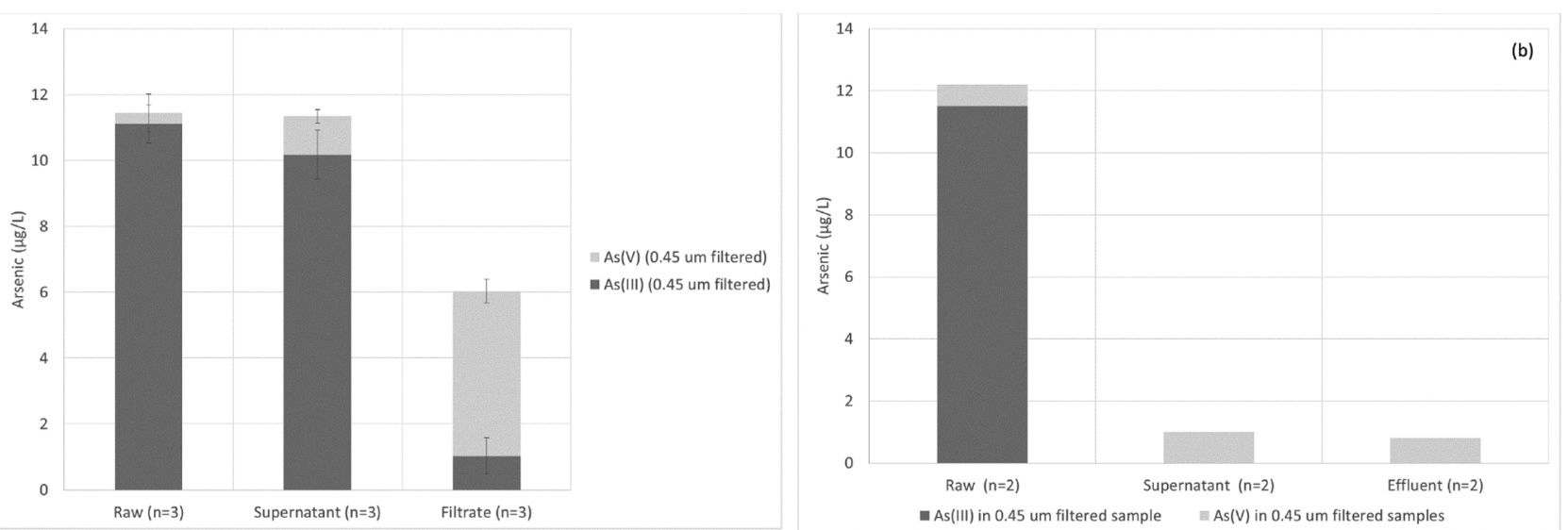

Fig. 6. Dissolved As species in raw, supernatant and filtrate (a) without and (b) with $\mathrm{MnO}_{4^{-}}-\mathrm{Fe}$ (III) dosing. Supernatant refers the water storage on the top of the filter bed.

\subsection{Influence of $\mathrm{MnO}_{4}-\mathrm{Fe}(\mathrm{III})$ dosing on filter backwash solids}

\subsubsection{Settling characteristics of filter backwash solids}

Fig. 7 presents the results of turbidity measurements in the top $10 \mathrm{~cm}$ of the backwash water samples as a function of time, as well as a visual comparison of the beginning $(t=0)$ and the end $(t=60 \mathrm{~min})$ of settling tests among the backwash water samples that were collected under three conditions: without dosing (no dose), i.e. prior to the upgrade, with only dosing $1.2 \mathrm{mg} / \mathrm{L} \mathrm{MnO}_{4^{-}}$and with dosing $1.2 \mathrm{mg} / \mathrm{L}$ $\mathrm{MnO}_{4^{-}}$and $1.8 \mathrm{mg} / \mathrm{L} \mathrm{Fe}(\mathrm{III})$. The color of the backwash water with $\mathrm{MnO}_{4}$ - and $\mathrm{MnO}_{4^{-}}-\mathrm{Fe}$ (III) dosing was darker, indicating the presence of solid phase $\mathrm{MnO}_{\mathrm{x}}$. The presence of $\mathrm{Mn}$ was also confirmed when backwash water samples were analyzed for $\mathrm{Fe}$ and $\mathrm{Mn}$ concentration by ICP-MS (see S2). The backwash water samples with $\mathrm{MnO}_{4^{-}}$and $\mathrm{MnO}_{4}-\mathrm{Fe}(\mathrm{III})$ dose settled faster than the sample collected at no dose (Fig. 7). Thus, the dosing of $\mathrm{MnO}_{4^{-}}$and $\mathrm{MnO}_{4^{-}}-\mathrm{Fe}$ (III) improved the settling rate of the filter backwash solids.

The dosing of $\mathrm{MnO}_{4}$ - might have modified the floc characteristics by altering the molecular-scale structure of the Fe(III)-precipitates in backwash solids. The structure of Fe-oxides depends largely on the synthesis conditions $[64,66]$ and since dosing of $\mathrm{MnO}_{4^{-}}$oxidized $\mathrm{Fe}(\mathrm{II})$ faster than $\mathrm{O}_{2}$, the molecular-scale structure of the produced $\mathrm{Fe}(\mathrm{III})$ precipitates might also be affected. Therefore, the backwash water solids produced under two conditions: without dosing (no dose), i.e. prior to the upgrade and with only dosing $1.2 \mathrm{mg} / \mathrm{L} \mathrm{MnO}_{4}$ - were characterized by Fe K-edge XAS (XANES and EXAFS) and XRD.

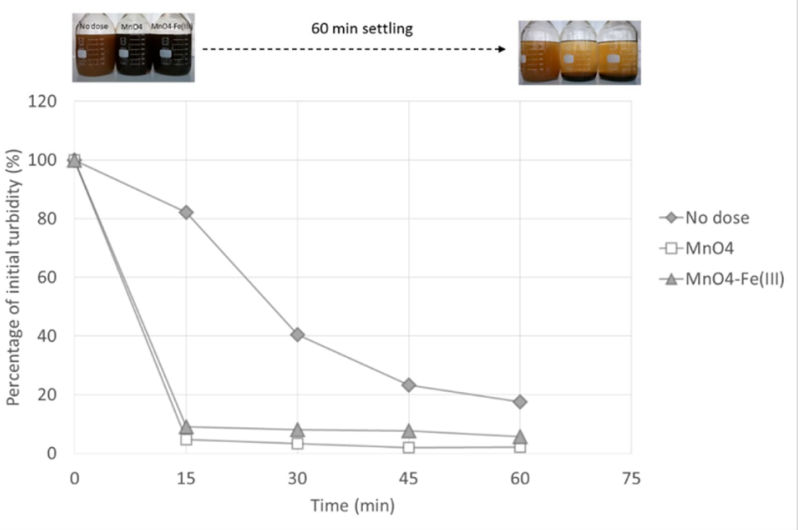

Fig. 7. Decrease in backwash water turbidity as a function of time. Photos on top show backwash water samples at the beginning $(t=0)$ and end $(\mathrm{t}=60 \mathrm{~min})$ of the settling test.

\subsubsection{Characterization of backwash water solids}

Fig. 8 shows the Fe-K edge XANES and EXAFS spectra of the backwash solids collected from the full scale filter. It can be observed that the position of the absorption edge in the XANES spectra (Fig. 8(a)) of the sample with no dose and with $\mathrm{MnO}_{4}$ - dose were similar and matched the absorption edge of the lepidocrocite and ferrihydrite XANES spectrum. This result shows that the Fe in both samples was primarily present as Fe(III). The oscillations in the post-edge region of the XANES spectra were similar for both the samples, but showed a slight shoulder (highlighted by the arrows in Fig. 8(a)) near the absorption maximum. This oscillation was more pronounced than in the ferrihydrite and lepidocrocite XANES spectra.

The Fe K-edge EXAFS spectra (Fig. 8(b)) of the samples showed a roughly symmetric first oscillation from 3.5 to $4.5 \AA^{-1}$, a major fingerprint of poorly-crystalline Fe(III) precipitates. The first oscillation of the samples matches both the 2-line ferrihydrite reference spectrum and the silicate-rich hydrous ferric oxide (Si-HFO) reference spectrum. These two reference spectra represent poorly-ordered Fe(III)-precipitate phases that form via rapid oxidation of $\mathrm{Fe}(\mathrm{II})$ or polymerization of $\mathrm{Fe}$ (III) salts in the presence of strongly-sorbing oxyanions (e.g. silicate, phosphate) and have been characterized previously [64]. In addition, the small beat near $5.0-5.2 \AA^{-1}$ in the ferrihydrite EXAFS spectrum, which is due to the corner-sharing Fe polyhedra, was weakened or absent in the spectra of both the backwash solids samples. The weakened feature indicative of corner-sharing Fe polyhedral in the backwash samples can be explained by the presence of silica in water during Fe(III) precipitation [64]. Finally, the peak near $6.2 \AA^{-1}$ was reduced in the backwash solids and the oscillations at $\mathrm{k}>9 \AA^{-1}$ in the $\mathrm{MnO}_{4}$ sample were broadened relative to lepidocrocite. Therefore, the XAS data showed that $\mathrm{Fe}$ in both the backwash solid samples was present as poorly-crystalline $\mathrm{Fe}(\mathrm{III})$ precipitates with structures that have slightly less polyhedral connectivity than ferrihydrite, regardless of the presence or absence of $\mathrm{MnO}_{4}$.

The XRD data (Fig. 9) of both the backwash solids samples were similar and showed only the broad peaks indicative of poorly crystalline hydrous ferric oxide. This result was consistent with the XAS data. Although Mn was present in the samples (much higher concentration in $\mathrm{MnO}_{4^{-}}$dosed sample, $\mathrm{Mn}: \mathrm{Fe}>0.3 \mathrm{~g}: \mathrm{g}$, see S2), no evidence for any crystalline Mn oxides was observed in the XRD patterns. This result suggests that $\mathrm{Mn}$ in the solid phase was present as a nanocrystalline solid, such as poorly-ordered birnessite, or perhaps was incorporated into the structure of the nanocrystalline hydrous ferric oxide, which has been observed previously during the co-precipitation of Mn with Fe(III) precipitates $[69,70]$. Although neither of these possible Mn coordination environments would produce strong Bragg diffraction peaks, which is consistent with our XRD data, we note that identifying the exact Mn speciation in the solid phase requires additional structural information. 

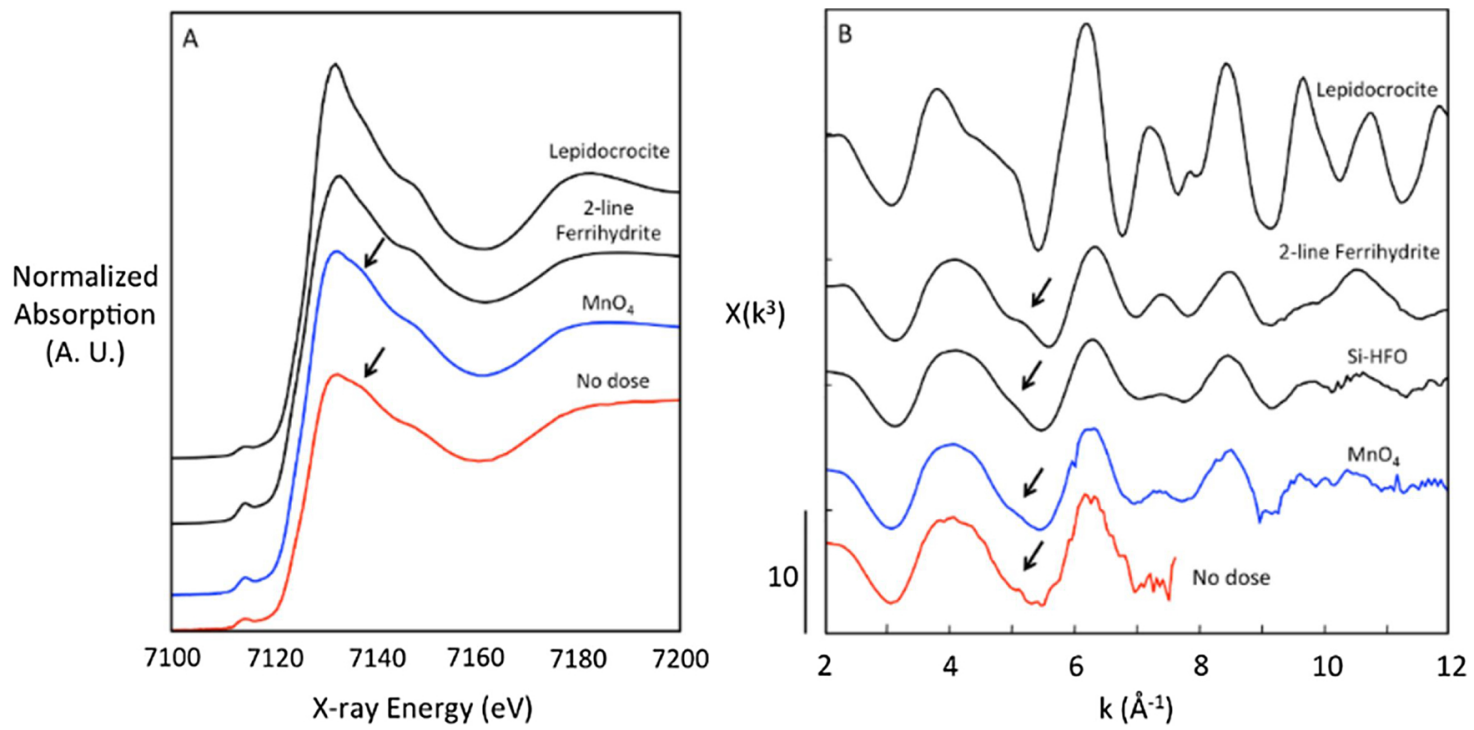

Fig. 8. (a) Fe K-edge XANES and (b) EXAFS spectra. Samples without dose (red) and with $\mathrm{MnO}_{4^{-}}$(blue).

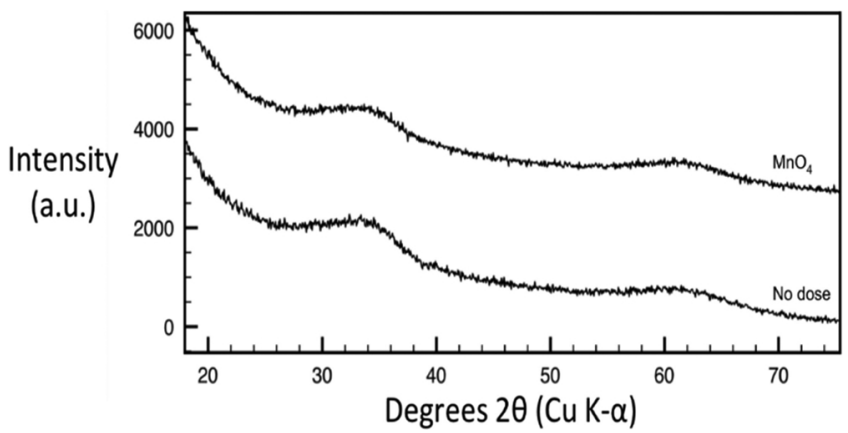

Fig. 9. X-ray diffraction patterns of the rapid sand filter backwash solids.

Because we observed that $\mathrm{MnO}_{4}$ - dosing alters substantially the settling characteristics of the backwash solids, and that $\mathrm{MnO}_{4^{-}}$dosing did not impact solid phase Fe speciation, it is likely that Mn speciation plays a critical role in determining the macroscopic properties of the backwashed solids. Therefore, further investigation to elucidate the mechanism of $\mathrm{Mn}$ incorporation in the flocs, and the subsequent impact on floc size, density, filterability and settling is required.

\section{Conclusions}

This study concludes that $\mathrm{MnO}_{4^{-}}-\mathrm{Fe}(\mathrm{III})$ dosing is an effective technique to improve As(III) removal at groundwater treatment facilities that typically use aeration —rapid sand filtration for drinking water production. At WTP Dorst, a typical groundwater treatment facility in the Netherlands, drinking water As concentrations of $<1 \mu \mathrm{g} / \mathrm{L}$ were achieved with $1.2 \mathrm{mg} / \mathrm{L} \mathrm{MnO}_{4^{-}}$and $1.8 \mathrm{mg} / \mathrm{L} \mathrm{Fe}(\mathrm{III})$, based on the outcomes of systematic batch and pilot study. The optimized combination of $\mathrm{MnO}_{4^{-}}$and $\mathrm{Fe}(\mathrm{III})$ doses did not decrease the removal efficiency of $\mathrm{Fe}(\mathrm{II}), \mathrm{Mn}(\mathrm{II})$ and $\mathrm{NH}_{4}{ }^{+}$, although the removal patterns of $\mathrm{Fe}$ (II) and $\mathrm{Mn}$ (II) were altered. In the absence of $\mathrm{MnO}_{4^{-}}-\mathrm{Fe}(\mathrm{III})$ dose, a significant part of Fe precipitation and the complete precipitation of $\mathrm{Mn}$ occurred in the filter bed whereby with $\mathrm{MnO}_{4}-\mathrm{Fe}(\mathrm{III})$ dosing, both $\mathrm{Fe}$ and $\mathrm{Mn}$ were completely precipitated in the supernatant, before entering the filter bed, and resulted in a shortening of the filter run time. The dosing of $\mathrm{MnO}_{4^{-}}-\mathrm{Fe}$ (III) improved the settling rate of backwash solids, which was not attributed to changes in molecular-scale structure of Fe-precipitates that form during treatment, but to the increased Mn concentration in the backwash solids.

\section{Acknowledgements}

This research is supported by the TKI Water Technology Programme of the Dutch Government and companies including Brabant Water, Evides Dunea, Aqua Minerals, Carus and Maltha group. AA wants to thank Doris van Halem, Jink Gude and Luuk Rietveld at Sanitary Engineering Dept. of Technical University of Delft for their valuable input during the project. The authors acknowledge the comments from both the anonymous reviewers which improved the paper substantially.

\section{Appendix A. Supplementary data}

Supplementary material related to this article can be found, in the online version, at doi:https://doi.org/10.1016/j.jwpe.2018.10.014.

\section{References}

[1] K.M. McCarty, H.T. Hanh, K.W. Kim, Arsenic geochemistry and human health in South East Asia, Rev. Environ. Health 26 (1) (2011) 71-78.

[2] S. Murcott, Arsenic Contamination in the World, IWA Publishing, London, UK, 2012.

[3] M.F. Naujokas, B. Anderson, H. Ahsan, H.V. Aposhian, J.H. Graziano, C. Thompson, W.A. Suk, The broad scope of health effects from chronic arsenic exposure: update on a worldwide public health problem, Environ Health Perspect 121 (3) (2013) 295-302.

[4] P. Bhattacharya, S.H. Frisbie, E. Smith, R. Naidu, G. Jacks, B. Sarkar, B. Sarkar (Ed.), Handbook of Heavy Metals in the Environment, Taylor \& Francis Inc., New York, 2002, pp. 145-215.

[5] R.P. Borba, B.R. Figueiredo, J. Matschullat, Geochemical distribution of arsenic in waters, sediments and weathered gold mineralized rocks from Iron Quadrangle, Brazil. Environmental Geology 44 (1) (2003) 39-52.

[6] J. Bundschuh, J.P. Maity, S. Mushtaq, M. Vithanage, S. Seneweera, J. Schneider, P. Bhattacharya, N.I. Khan, I. Hamawand, L.R.G. Guilherme, K. Reardon-Smith, F. Parvez, N. Morales-Simfors, S. Ghaze, C. Pudmenzky, L. Kouadio, C.Y. Chen, Medical geology in the framework of the sustainable development goals, Sci. Total Environ. 581-582 (2017) 87-104.

[7] O. Gunduz, C. Simsek, A. Hasozbek, Arsenic pollution in the groundwater of Simav Plain, Turkey: Its impact on water quality and human health, Water Air Soil Pollut. $205(1-4)(2010)$ 43-62.

[8] A.M. MacDonald, H.C. Bonsor, K.M. Ahmed, W.G. Burgess, M. Basharat, R.C. Calow, A. Dixit, S.S.D. Foster, K. Gopal, D.J. Lapworth, R.M. Lark, M. Moench,

A. Mukherjee, M.S. Rao, M. Shamsudduha, L. Smith, R.G. Taylor, J. Tucker, F. Van Steenbergen, S.K. Yadav, Groundwater quality and depletion in the Indo-Gangetic Basin mapped from in situ observations, Nat. Geosci. 9 (10) (2016) 762-766.

[9] H. Marszałek, M. Wasik, Influence of arsenic-bearing gold deposits on water quality in Zloty Stok mining area (SW Poland), Environ. Geol. 39 (8) (2000) 888-892.

[10] J.O. Nriagu, P. Bhattacharya, A.B. Mukherjee, J. Bundschuh, R. Zevenhoven, R.H. Loeppert, Trace Metals and Other Contaminants in the Environment, (2007), pp. 3-60.

[11] N.C. Woo, M.C. Choi, Arsenic and metal contamination of water resources from mining wastes in korea, Environ. Geol. 40 (3) (2001) 305-311. 
[12] P. Bhattacharya, A.H. Welch, K.G. Stollenwerk, M.J. McLaughlin, J. Bundschuh, G. Panaullah, Arsenic in the environment: biology and chemistry, Sci. Total Environ. 379 (2) (2007) 109-120.

[13] F.W. Pontius, K.G. Brown, C.-J. Chen, Health implications of arsenic in drinking water, Am.Water Works Assoc. 86 (9) (1994) 52-63.

[14] P.L. Smedley, D.G. Kinniburgh, A review of the source, behaviour and distribution of arsenic in natural waters, Appl. Geochem. 17 (5) (2002) 517-568.

[15] J.F. Ferguson, J. Gavis, A review of the arsenic cycle in natural waters, Water Res. 6 (11) (1972) 1259-1274.

[16] S. Wang, C.N. Mulligan, Occurrence of arsenic contamination in Canada: sources, behavior and distribution, Sci. Total Environ. 366 (2006) 701-721.

[17] U. Schuhmacher-Wolz, H.H. Dieter, D. Klein, K. Schneider, Oral exposure to inorganic arsenic: evaluation of its carcinogenic and non-carcinogenic effects, Crit. Rev. Toxicol. 39 (4) (2009) 271-298.

[18] A.H. Smith, C. Hopenhayn-Rich, M.N. Bates, H.M. Goeden, I. Hertz-Picciotto, H.M. Duggan, R. Wood, M.J. Kosnett, M.T. Smith, Cancer risks from arsenic in drinking water, Environ. Health Perspect. 97 (1992) 259-267.

[19] M. Vahter, Health effects of early life exposure to arsenic, Basic Clin. Pharmacol. Toxicol. 102 (2) (2008) 204-211.

[20] M. Vahter, R. Gardner, S. Ahmed, M. Kippler, J.D. Hamadani, F. Tofail, R. Raqib, Effects of Early-life Arsenic Exposure on Child Health and Development, (2012), pp. 173-174.

[21] F. Kozisek, Best practice Guide on the control of arsenic, in: P. Bhattacharya, D.A. Polya, D. Jovanovic (Eds.), Drinking Water, IWA Publishing, London, UK, 2017.

[22] C.W. Schmidt, Low-dose arsenic: in search of a risk threshold, Environ. Health Perspect. 122 (5) (2014) A131-134.

[23] WHO, Arsenic in Drinking-water: Background Document for Development of WHO Guidelines for Drinking-water Quality, WHO Press, Geneva, Switzerland, 2011 , p. 16.

[24] P. Van der Wens, K. Baken, M. Schriks, ) Arsenic at low concentrations, in: P. Bhattacharya, M. Vahter, J. Jarsjö, J. Kumpiene, A. Ahmad, C. Sparrenbom, G. Jacks, M.E. Donselaar, J. Bundschuh, R. Naidu (Eds.), Dutch Drinking Water: Assessment of Removal Costs and Health Benefits, CRC Press, Stockholm, Sweden, 2016, pp. 563-564.

[25] A. Ahmad, S. Kools, M. Schriks, P. Stuyfzand, B. Hofs, Arsenic and Chromium Concentrations and Their Speciation in Groundwater Resources and Drinking Water Supply in The Netherlands p. 78, KWR Water Cycle Research Institute, Nieuwegein, The Netherlands, 2015.

[26] P. Stuyfzand, P. van Rossum, I. Mendizabal, T. Appelo (Ed.), Arsenic in Groundwater - a World Problem, Netherlands National Committee of the IAH, Utrecht, The Netherlands, 2008, pp. 102-125.

[27] P.J. de Moel, J.Q.J.C. Verberk, J.C. van Dijk, Drinking Water: Principles and Practices, World Scientific Publishing Co. Pte. Ltd., Delft, The Netherlands, 2006.

[28] S. Jessen, F. Larsen, C.B. Koch, E. Arvin, Sorption and Desorption of Arsenic to Ferrihydrite in a Sand Filter, Environ. Sci. Technol. 39 (20) (2005) 8045-8051.

[29] C.G.E.M. Van Beek, T. Hiemstra, B. Hofs, M.M. Bederlof, J.A.M. van Paassen, G.K. Reijnen, Homogeneous, heterogeneous and biological oxidation of iron(II) in rapid sand filtration, J. Water Supply Res. Technol. 61 (1) (2012) 1-2012.

[30] D. Vries, C. Bertelkamp, F. Schoonenberg Kegel, B. Hofs, J. Dusseldorp, J.H. Bruins, W. de Vet, B. van den Akker, Iron and manganese removal: recent advances in modelling treatment efficiency by rapid sand filtration, Water Res. 109 (2017) $35-45$.

[31] D. Diem, W. Stumm, Is dissolved $\mathrm{Mn}^{+2}$ being oxidized by $\mathrm{O}_{2}$ in absence of Mnbacteria and surface catalysts? Geochim. Cosmochim. Acta 48 (1984) 1571-1573.

[32] D.A. Lytle, T.J. Sorg, V.L. Snoeyink, Optimizing arsenic removal during iron removal: theoretical and practical considerations, J. Water Supply: Res. Technol. AQUA 54 (8) (2005) 545-560.

[33] J.H. Bruins, B. Petrusevski, Y.M. Slokar, J.C. Kruithof, M.D. Kennedy, Manganese removal from groundwater: characterization of filter media coating, Desalin. Water Treat. 55 (7) (2015) 1851-1863.

[34] I.A. Katsoyiannis, A. Zikoudi, S.J. Hug, Arsenic removal from groundwaters containing iron, ammonium, manganese and phosphate: A case study from a treatment unit in northern Greece, Desalination 224 (1-3) (2008) 330-339.

[35] W. De Vet, Biological Drinking Water Treatment Of Anaerobic Groundwater In Trickling Filters, Technical University of Delft, Delft, 2011.

[36] J.C.J. Gude, L.C. Rietveld, D. van Halem, Fate of low arsenic concentrations during full-scale aeration and rapid filtration, Water Res. 88 (2016) 566-574.

[37] L.S. McNeill, M. Edwards, Soluble arsenic removal at water treatment plants, Am. Water Works Assoc. 87 (4) (1995) 105-113.

[38] D.A. Lytle, A.S. Chen, T.J. Sorg, S. Phillips, K. French, Microbial As(III) oxidation in water treatment plant filters, Am. Water Works Assoc. 99 (12) (2007) 72-86.

[39] S. Sorlini, F. Gialdini, M.C. Collivignarelli, Survey on full-scale drinking water treatment plants for arsenic removal in Italy, Water Pract. Technol. 9 (1) (2014) 42-51.

[40] S. Dixit, J.G. Hering, Comparison of arsenic(V) and arsenic(III) sorption onto iron oxide minerals: Implications for arsenic mobility, Environ. Sci. Technol. 37 (18)
(2003) 4182-4189.

[41] J.G. Hering, P.-Y. Chen, J.A. Wilkie, M. Elimelech, S. Liang, Arsenic removal by ferric chloride, Am. Water Works Assoc. 88 (4) (1996) 155-167.

[42] J. Qiao, Z. Jiang, B. Sun, Y. Sun, Q. Wang, X. Guan, Arsenate and arsenite removal by FeCl3: Effects of pH, As/Fe ratio, initial As concentration and co-existing solutes, Sep. Purif. Technol. 92 (2012) 106-114.

[43] C. Su, R.W. Puls, Arsenate and Arsenite Removal by Zerovalent Iron: Effects of Phosphate, Silicate, Carbonate, Borate, Sulfate, Chromate, Molybdate, and Nitrate, Relative to Chloride, Environ. Sci. Technol. 35 (22) (2001) 4562-4568.

[44] J.A. Wilkie, J.G. Hering, Adsorption of arsenic onto hydrous ferric oxide: effects of adsorbate/adsorbent ratios and co-occurring solutes, Colloids Surf. A Physicochem. Eng. Asp. 107 (1996) 97-110.

[45] J. Youngran, M. Fan, J. Van Leeuwen, J.F. Belczyk, Effect of competing solutes on arsenic(V) adsorption using iron and aluminum oxides, J. Environ. Sci. 19 (8) (2007) 910-919.

[46] J.C.J. Gude, L.C. Rietveld, D. van Halem, As(III) oxidation by MnO2 during groundwater treatment, Water Res. 111 (2017) 41-51.

[47] L.C. Roberts, S.J. Hug, T. Ruettimann, M.M. Billah, A.W. Khan, M.T. Rahman, Arsenic Removal with Iron(II) and Iron(III) in Waters with High Silicate and Phosphate Concentrations, Environ. Sci. Technol. 38 (1) (2004) 307-315.

[48] C.K. Jain, I. Ali, Arsenic: occurrence, toxicity and speciation techniques, Water Res. 34 (17) (2000) 4304-4312.

[49] M.L. Pierce, C.B. Moore, Adsorption of arsenite and arsenate on amorphous iron hydroxide, Water Res. 16 (7) (1982) 1247-1253.

[50] K.P. Raven, A. Jain, R.H. Loeppert, Arsenite and arsenate adsorption on ferrihydrite: Kinetics, equilibrium, and adsorption envelopes, Environ. Sci. Technol. 32 (3) (1998) 344-349.

[51] J.C. Hsu, C.J. Lin, C.H. Liao, S.T. Chen, Removal of As(V) and As(III) by reclaimed iron-oxide coated sands, J. Hazard. Mater. 153 (1-2) (2008) 817-826.

[52] D. Lakshmanan, D. Clifford, G. Samanta, Arsenic removal by coagulation with aluminum, Iron, titanium, and zirconium, Am. Water Works Assoc. 100 (2) (2008) 76-88.

[53] P. Frank, D. Clifford, Arsenic(III) oxidation and removal from drinking water, p. 69, US Environmental Protection Agency, Cincinnati (1986) OH.

[54] M.-J. Kim, J. Nriagu, Oxidation of arsenite in groundwater using ozone and oxygen, Sci. Total Environ. 247 (1) (2000) 71-79.

[55] M. Bissen, F.H. Frimmel, Arsenic - A review. Part II: oxidation of arsenic and its removal in water treatment, Acta Hydrochim. Hydrobiol. 31 (2) (2003) 97-107.

[56] G. Ghurye, D. Clifford, Laboratory Study on the Oxidation of Arsenic III to As V, p. 87, Unites States Environmental Protection Agency, Washington DC, 2001.

[57] S. Lihua, L. Ruiping, X. Shengji, Y. Yanling, L. Guibai, Enhanced As(III) removal with permanganate oxidation, ferric chloride precipitation and sand filtration as pretreatment of ultrafiltration, Desalination 243 (1) (2009) 122-131.

[58] S. Sorlini, F. Gialdini, Conventional oxidation treatments for the removal of arsenic with chlorine dioxide, hypochlorite, potassium permanganate and monochloramine, Water Res. 44 (19) (2010) 5653-5659.

[59] P. Smeets, G. Medema, J. Dijk, The Dutch Secret: How to Provide Safe Drinking Water Without Chlorine in The Netherlands, (2009).

[60] U. Von Gunten, Ozonation of drinking water: Part II. Disinfection and by-product formation in presence of bromide, iodide or chlorine, Water Res. 37 (7) (2003) 1469-1487.

[61] M. Borho, P. Wilderer, Optimized removal of arsenate(III) by adaptation of oxidation and precipitation processes to the filtration step, Water Sci. Technol. 34 (9) (1996) 25-31.

[62] X. Guan, J. Ma, H. Dong, L. Jiang, Removal of arsenic from water: Effect of calcium ions on As(III) removal in the KMnO4-Fe(II) process, Water Res. 43 (20) (2009) 5119-5128.

[63] S. Bordoloi, S.K. Nath, S. Gogoi, R.K. Dutta, Arsenic and iron removal from groundwater by oxidation-coagulation at optimized pH: laboratory and field studies, J. Hazard. Mater. 260 (2013) 618-626.

[64] C.M. Van Genuchten, J. Pena, S.E. Amrose, A.J. Gadgil, Structure of Fe(III) precipitates genberated by the electrolytric dissolution of $\mathrm{Fe}(0)$ in the presence of groundwater ions, Geochim. Cosmochim. Acta 127 (2014) 285-304.

[65] D.A. Clifford, L. Ceber, S. Chow, Separation of Arsenic III and AsV by Ion Exchange, AWWA, Denver, Colo. (1983).

[66] R.M. Cornell, U. Schwertmann, The Iron Oxides: Structure, Properties, Reactions, Occurances and Uses, WILEY-VCH Verlag GmbH \& Co., 2003.

[67] M. Edwards, Chemistry of arsenic removal during coagulation and Fe-Mn oxidation, Am. Water Works Assoc. (1994) 64-78.

[68] W. Driehaus, R. Seith, M. Jekel, Oxidation of arsenate(III) with manganese oxides in water treatment, Water Res. 29 (1) (1995) 297-305.

[69] M.H. Ebinger, D.G. Schulze, Mn-Substituted Goethite and Fe-Substituted Groutite Synthesized at Acid pH, Clays Clay Miner. 37 (2) (1989) 151-156.

[70] C.M. van Genuchten, J. Pena, Mn(II) Oxidation in Fenton and Fenton Type Systems: Identification of Reaction Efficiency and Reaction Products, Environ. Sci. Technol. 51 (5) (2017) 2982-2991. 